\title{
Initiation of protein synthesis in mammalian cells
}

\author{
Virginia M. PAIN \\ Biochemistry Laboratory, School of Biological Sciences, University of Sussex, Falmer, Brighton BN1 9QG, U.K.
}

\section{Introduction}

Detailed knowledge of the mechanism and regulation of protein synthesis in eukaryotic cells has only emerged over the last 15 years. A phase of rapid development was in the early to middle 1970 s, when most of the currently-known initiation factors were purified and their roles established by stepwise assembly of initiation complexes in vitro from the purified components. It was also found that phosphorylation of the initiation factor eIF-2 had an important role in the regulation of translation in reticulocytes. Another period of rapid advance began about 3-4 years ago. Further study of the role of phosphorylation of eIF-2 led to the discovery of a new initiation factor. In addition the characterization of yet another factor triggered progress in understanding the complicated process by which initiating $40 \mathrm{~S}$ ribosomal subunits bind to mRNA. The other outstanding change has been the expansion of interest in translational control in cells and tissues other than the reticulocyte. This has been facilitated by the increasing availability of antibodies specific for eukaryotic initiation factors and the use of immunoblotting techniques to investigate the cellular concentrations and phosphorylation status of these factors in cells under different physiological conditions.

Even in modern text-books of biochemistry, eukaryotic protein synthesis tends to be a 'poor relation' in comparison with the process in prokaryotes [1,2], although there are honourable exceptions $[3,4]$. Some books have immortalized theories on regulation that have long been superceded $[2,5,6]$. Several reviews cover work published up to about 1982 [7-10]. In addition, two full-length reviews appeared more recently, one dealing with certain specific aspects of regulation [11] and the other a well-balanced account of current views of mechanism [12]. Here I aim to summarize present knowledge of the mechanism of initiation of protein synthesis in mammalian cells, and of its quantitative regulation, with particular reference to the most recent developments. It is not possible to cover all aspects in detail, and I have concentrated on the control of overall rates of translation rather than selection mechanisms governing relative rates of translation of individual mRNA species. In reference citation I have discriminated in favour of more recent articles and those published in major journals in preference to those in specialized symposium volumes and monographs that may not be so easily accessible to the reader.

Mechanism of initiation of translation in mammalian cells

The overall pathway is shown in Fig. 1 and summarized in the legend to that Figure. It can be seen that there are four main steps, each involving the interaction of several components. These are described in more detail in this section. Table 1 lists the initiation factors discussed in this review.

Formation of the ternary complex, [eIF-2 $\cdot$ GTP-MettRNA $A_{f}$. This complex forms rapidly in vitro when the individual, purified components are mixed under appropriate conditions; the reaction is easily monitored by using $\left.{ }^{35} \mathrm{~S}\right] \mathrm{Met}-\mathrm{tRNA} \mathrm{f}_{\mathrm{f}}$, which is trapped on nitrocellulose filters when bound to eIF-2. The reaction has been extensively characterized and eIF- 2 has been purified from a wide variety of cells and tisues. eIF- 2 consists of three dissimilar subunits, $\alpha, \beta$ and $\gamma$, whose molecular masses, determined by sedimentation equilibrium centrifugation, are 38000,35000 and $55000 \mathrm{Da}$ respectively [13]. On SDS/polyacrylamide-gel electrophoresis, however, the $\beta$ subunit usually belies its molecular mass, and runs close to the $\gamma$ subunit. Some preparations of eIF-2 appear to lack the $\beta$ subunit $[14,15]$. This may be a true phenomenon, but in some cases could be an artifact due to the $\beta$ and $\gamma$ subunits becoming superimposed during analysis, possibly because of limited proteolysis during preparation [16-18]. Surprisingly, there are still significant gaps in our knowledge of even the most basic mechanisms involved in the formation of the ternary complex. It was originally suggested that the GTP ligand binds to the $\alpha$ subunit and Met-tRNA to the $\beta$ subunit [19], but more recent work using affinity labelling with photo-reactive analogues of GTP has indicated that guanine nucleotides bind either to the $\gamma[20]$ or the $\beta$ (W. C. Merrick, personal communication) subunits. In the latter study the analytical system used was capable of distinguishing unambiguously between the $\beta$ and $\gamma$ subunits, and both studies included controls demonstrating specificity of association. The reason for the discrepancy is not clear, but it is possible that the formation of the nucleotide binding site actually involves more than one subunit of the factor.

The formation of a binary complex between eIF- 2 and GTP is thought to precede the addition of Met-tRNA , since the initiator tRNA will not bind in vitro in the absence of the nucleotide. GTP can be replaced in the reaction by non-hydrolysable analogues, but the formation of a binary complex with GDP completely prevents

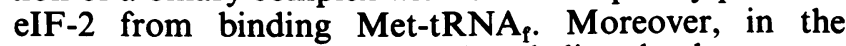
presence of $\mathrm{Mg}^{2+}$ at concentrations believed to be present in cells, the affinity of the factor for GDP is about 100-fold higher than that for GTP [21]. To appreciate the significance of this, one must remember that at the end of each round of initiation the release of eIF-2 from the ribosome is associated with the hydrolysis of the GTP

\footnotetext{
Abbreviations used: eIF, eukaryotic initiation factor; GEF, guanine nucleotide exchange factor; HCR, haem-controlled repressor; dsRNA, double-stranded RNA.
}

Vol. 235 


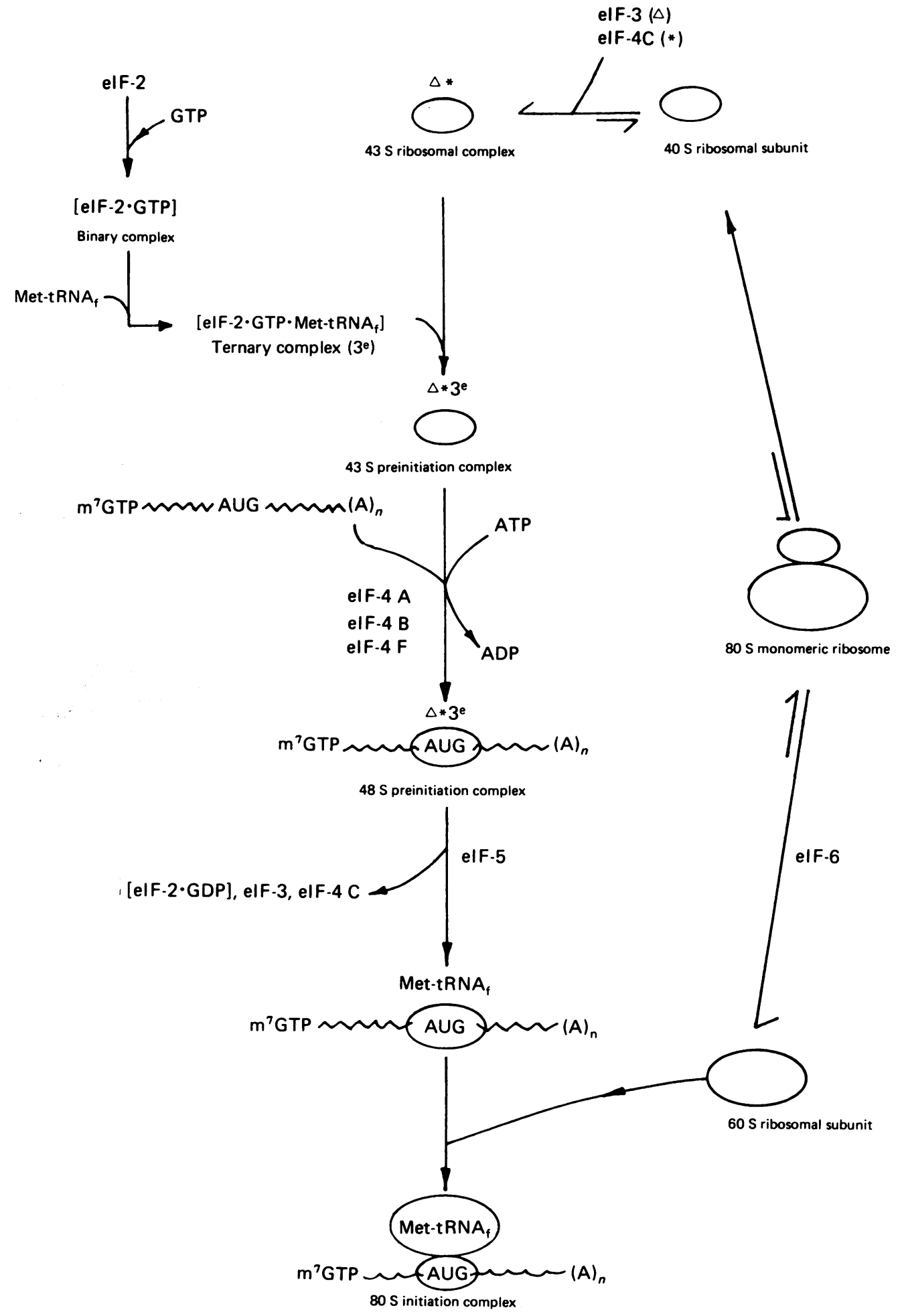

Fig. 1. Initiation of protein synthesis in mammalian cells

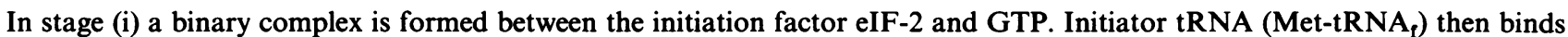
to this to form a ternary complex, [eIF-2 $\cdot$ GTP-Met-tRNA $A_{f}$, symbolized as $3^{\mathrm{e}}$ in later stages. In stage (ii) the ternary complex binds to a $43 \mathrm{~S}$ ribosomal complex to form a $43 \mathrm{~S}$ preinitiation complex. The formation of the $43 \mathrm{~S}$ ribosomal complex requires the dissociation of an $80 \mathrm{~S}$ ribosome into its constituent subunits; the $40 \mathrm{~S}$ subunit binds the initiation factors eIF-3 ( $\triangle$ ) and possibly eIF-4C $\left(^{*}\right)$. In stage (iii) the $43 \mathrm{~S}$ preinitiation complex binds to the $5^{\prime}$ end of an mRNA molecule, and then moves along the $5^{\prime}$ untranslated sequence until it reaches the correct initiation codon, usually the first AUG. Initiation factors eIF-4A, eIF-4B and eIF-4F are needed for mRNA binding, as well as the eIF-3 already bound to the $40 \mathrm{~S}$ subunit. ATP hydrolysis is also required. In stage (iv), eIF-5 promotes the release of the initiation factors bound to the $40 \mathrm{~S}$ subunit. This requires the hydrolysis of the GTP molecule that entered as part of the ternary complex. A $60 \mathrm{~S}$ ribosomal subunit can then bind to the [40 S $\cdot$ mRNA] complex, forming an $80 \mathrm{~S}$ initiation complex on the mRNA. 
Table 1. Eukaryotic initiation factors

\begin{tabular}{|c|c|c|}
\hline Factor & $\begin{array}{l}\text { Subunit composition and } \\
\text { approximate molecular mass (Da) }\end{array}$ & Putative function(s) \\
\hline eIF-2 & $\begin{array}{l}38000 \\
35000 \\
55000\end{array}$ & $\begin{array}{l}\text { Ternary complex formation; binding } \\
\text { of Met-tRNA } A_{f} \text { to } 40 \mathrm{~S} \text { subunit }\end{array}$ \\
\hline eIF-3 & $\begin{array}{l}\text { Nine to eleven subunits, ranging } \\
\text { from } 24000 \text { to } 120000\end{array}$ & $\begin{array}{l}\text { Maintenance of dissociated ribosomal } \\
\text { subunits (by association with } 40 \mathrm{~S} \\
\text { subunit); binding } 43 \mathrm{~S} \text { initiation complex } \\
\text { to mRNA }\end{array}$ \\
\hline eIF-4A & 46000 & $\begin{array}{l}\text { RNA-dependent ATPase; unwinding of } \\
\text { secondary structure at } 5^{\prime} \text { end of mRNA }\end{array}$ \\
\hline eIF-4B & 80000 & $\begin{array}{l}\text { Binding of } 43 \mathrm{~S} \text { initiation complex } \\
\text { to mRNA }\end{array}$ \\
\hline eIF-4C & 17000 & $\begin{array}{l}\text { Ribosome dissociation; } 60 \mathrm{~S} \text { subunit } \\
\text { joining }\end{array}$ \\
\hline eIF-4F & $\begin{array}{r}24000 \\
46000 \\
220000\end{array}$ & $\begin{array}{l}\text { Recognition of } 5^{\prime} \text { terminal cap structure } \\
\text { of mRNA }\end{array}$ \\
\hline eIF-5 & 125000 & $\begin{array}{l}\text { Ribosome-dependent GTPase; release of } \\
\text { eIF-2 and eIF-3 from initiation complex, } \\
\text { permitting } 60 \mathrm{~S} \text { subunit joining }\end{array}$ \\
\hline eIF-6 & 25000 & Ribosome dissociation \\
\hline GEF & $\begin{array}{l}27000 \\
37000 \\
52000 \\
67000 \\
85000\end{array}$ & Guanine nucleotide exchange on eIF-2 \\
\hline
\end{tabular}

molecule bound with it (Fig. 1). The high affinity of the factor for GDP makes it extremely likely that it is actually released as a binary [eIF-2.GDP] complex [22]. Based simply on the relative affinities of the two nucleotides, the displacement of the GDP by GTP, a necessary step to permit the participation of the eIF-2 molecule in a new round of initiation, would seem to be a difficult obstacle. Analogy with the role of the auxiliary elongation factor, EF-Ts, in Escherichia coli would suggest that this problem may be resolved in vivo by the existence of an enzyme-mediated recycling step, in which GDP is actively displaced from eIF-2 and subsequently replaced by GTP. An important development has been the isolation of a new initiation factor with such guanine nucleotide exchange activity. It has been extensively purified from reticulocytes [23-26] and other cells [27]. There is a good measure of agreement over the composition of this rather complex factor, which has major protein subunits of approx. 85000, 67000, 52000, 37000 and $27000 \mathrm{Da}$. Unfortunately, such unanimity does not extend to the nomenclature applied to the factor, which has been called variously eIF-2B [25,28-30], RF [24], eRF [26], SP [31] and guanine nucleotide exchange factor, or GEF $[27,32,33]$. I shall use the last of these terms, which is the functional definition, in this review. In addition, GEF activity is probably the basis of action of stimulatory activities described in earlier reports as anti-inhibitor [34], ESP $[35,36]$, sRF [37] and Co-eIF2C $[38,39]$.

The activity of GEF can be assayed in vitro by measuring (i) its ability to catalyse the displacement of [ $\left.{ }^{3} \mathrm{H}\right]$ GDP, previously bound to eIF-2, by unlabelled GTP or GDP at $\mathrm{Mg}^{2+}$ concentrations near the optimum for protein synthesis [24-27,31,32] or (ii) under similar conditions, its ability to promote binding of $\left[{ }^{35} \mathrm{~S}\right] \mathrm{Met}-$
tRNA $_{\mathrm{f}}$ to eIF-2 preparations that are partially or wholly in the form of [eIF-2. GDP] complexes [24-26]. The exact sequence of events involved in the nucleotide exchange is still uncertain, and the models that have been proposed so far are shown in Fig. $2[9,26,29,33]$. These models are discussed in greater detail in the review by Manchester [40]. They all propose a physical interaction between eIF-2 and GEF; this is suggested by the detection of eIF-2 in cell fractions in a form with sedimentation or gel filtration characteristics expected of a 'heavy' complex [25-27,34] and by the ability of the purified components to associate into complexes detectable on glycerol gradients $[26,41]$. This will be discussed further below.

eIF-2 is a substrate for protein kinases and phosphatases. The phosphorylation of the $\alpha(38000 \mathrm{Da})$ subunit by cyclic AMP-independent protein kinases is a major mechanism for regulating the rate of translation, and is discussed below. Phosphatase activity towards eIF-2 phosphorylated in this subunit has been studied [42-45] and an enzyme with this activity has been classified as a Type-2 protein phosphatase [46,47]. The $\beta$ subunit of eIF- 2 can be phosphorylated by various protein kinases, such as casein kinase II [48,49], and a proteinase-activated kinase[50] anda phospholipid-sensitive, calcium-activated kinase [51] with properties similar to those of protein kinase $\mathrm{C}$, but no connection has yet been established between the phosphorylation of this subunit and the activity of the factor, either in vivo or in vitro.

Formation of initiation complexes associated with the $40 \mathrm{~S}$ ribosomal subunit. In vitro, $40 \mathrm{~S}$ initiation complexes can be assembled simply from GTP, initiator tRNA and purified eIF-2 (the components of the ternary complex), together with salt-washed $40 \mathrm{~S}$ ribosomal subunits 
(a)

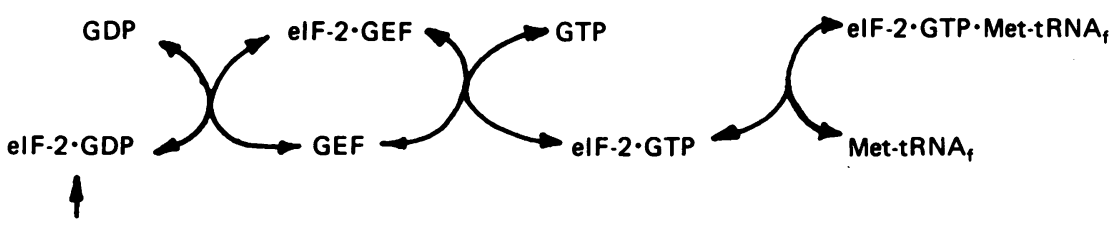

(b)

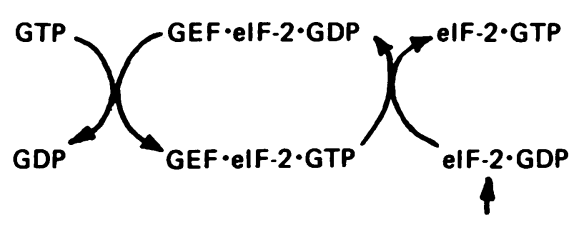

(c)
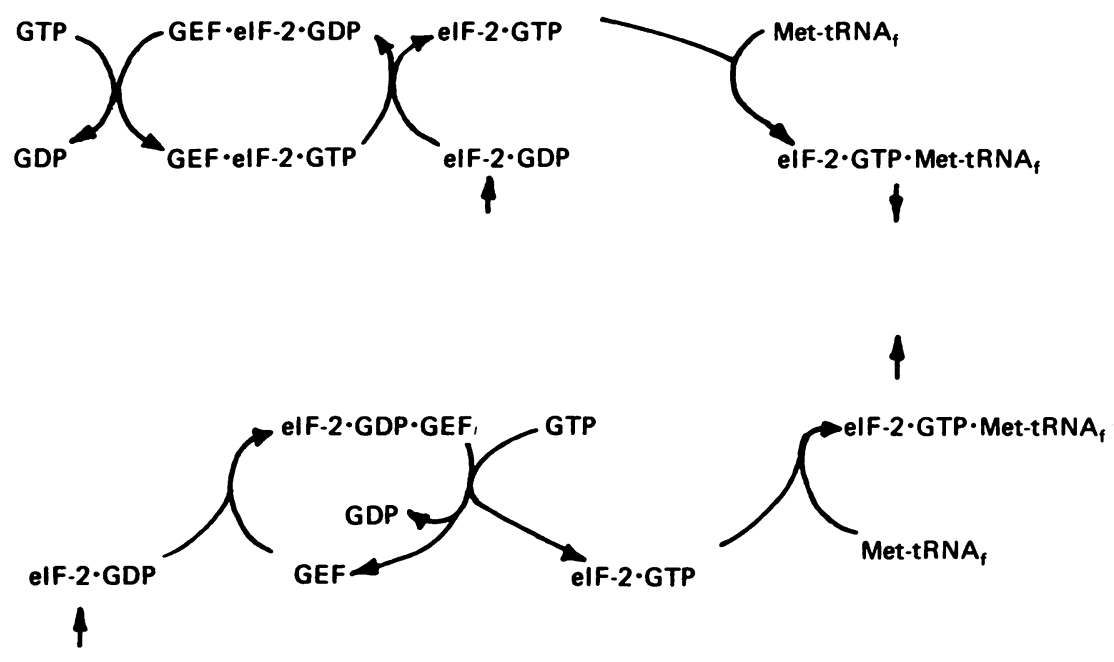

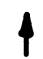

(d)

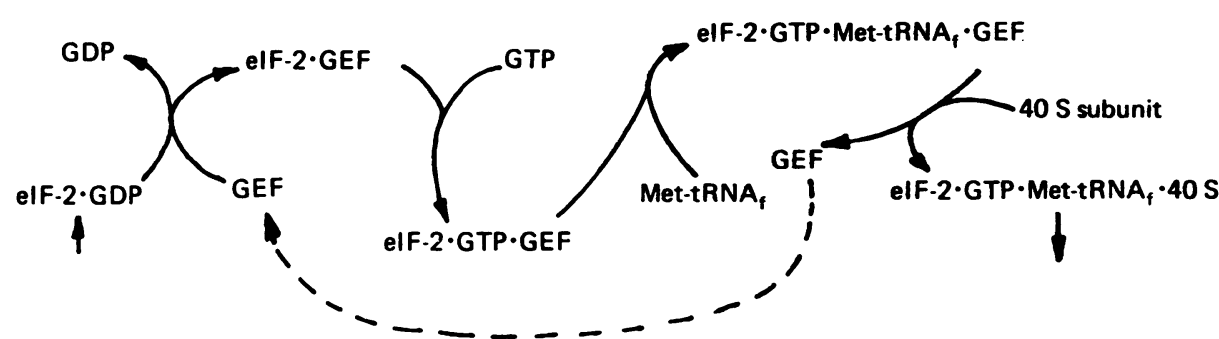

Fig. 2. Proposed mechanisms for interaction of elF-2 with the guanine nucleotide exchange factor (GEF)

In each model the [eIF-2.GDP] generated from the previous round of initiation is indicated by an inward pointing arrow and the first preinitiation complex of the new round is indicated by an outward pointing arrow. (a) From Ochoa [9]. GEF displaces the GDP from the [eIF-2 - GDP] complex released from the previous cycle of initiation, and forms an [eIF-2. GEF] complex. GEF is in turn displaced by GTP to give an [eIF-2.GTP] binary complex available for a new round of initiation. (b) From Safer

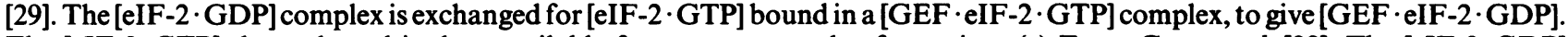
The [eIF-2 -GTP] thus released is then available for ternary complex formation. (c) From Goss et al. [33]. The [eIF-2 $\cdot$ GDP] complex binds to GEF to form [eIF-2 GDP. GEF]. The binding of GTP then releases the GDP and free GEF. (d) From Salimans et al. [26]. GEF displaces GDP from [eIF-2 - GDP] to give an [eIF-2 - GEF] complex. This then binds GTP and Met-tRNA to give a quaternary complex of $\left[\mathrm{eIF}-2 \cdot \mathrm{GTP} \cdot \mathrm{Met}-\mathrm{tRNA} \mathrm{f}_{\mathrm{f}} \cdot \mathrm{GEF}\right]$. The GEF is only displaced when $[\mathrm{eIF}-2 \cdot \mathrm{GTP} \cdot \mathrm{Met}-\mathrm{tRNA}$ ] is transferred to the $40 \mathrm{~S}$ ribosomal subunit.

[52-54]. However, other factors, notably eIF-3, enhance this association, at least in part by stabilizing the complex [52-55]. The use of radiolabelled factors showed all three subunits of eIF-2 and most or all of those of eIF-3 to be present in the complexes [53,54]. However, Salimans et al. [26] reported that the $\beta$ subunit of eIF-2 was incorporated into $40 \mathrm{~S}$ preinitiation complexes to a lesser extent than the $\alpha$ and $\gamma$ subunits. eIF-3 is a very large protein, containing nine to eleven subunits of total molecular mass about $700000 \mathrm{Da}[53,56]$. Its binding to $40 \mathrm{~S}$ ribosomal subunits appreciably increases their rate of sedimentation on sucrose density gradients, and it is common practice to refer to the complete complex as the $43 \mathrm{~S}$ preinitiation complex (Fig. 1). $40 \mathrm{~S}$ ribosomal 


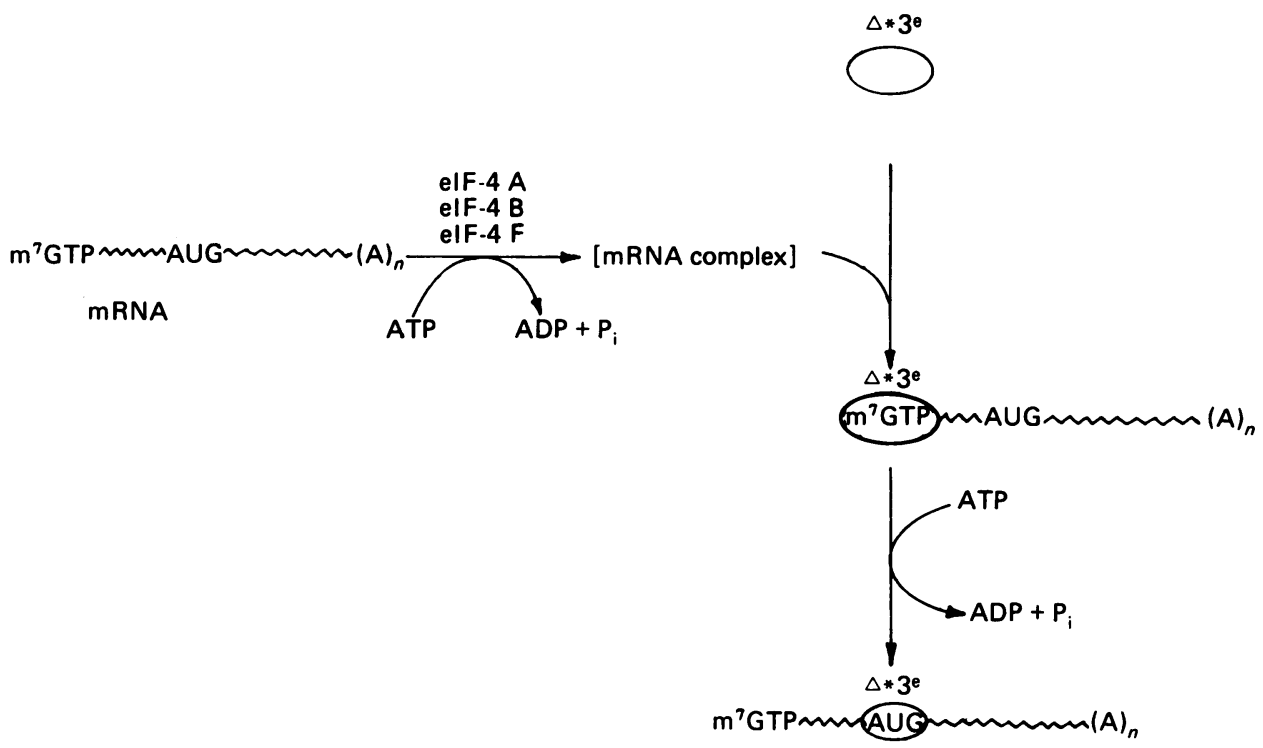

Fig. 3. Detailed view of the binding of mRNA to the $43 \mathrm{~S}$ preinitiation complex

The symbols are explained in the legend to Fig. 1. In the first stage mRNA interacts with eIF-4A, eIF-4B and eIF-4F, with the hydrolysis of ATP. A $43 \mathrm{~S}$ preinitiation complex can then bind at, or very near to, the $5^{\prime}$ terminal cap structure of the mRNA. The ribosomal subunit then moves along the $5^{\prime}$ untranslated sequence of the mRNA until it reaches the initiation site, usually the first AUG codon.

subunits labelled with $\left[{ }^{35}\right.$ S $]$ methionine in whole cells also sediment faster [57], indicating that in vivo the particle containing both eIF-2 and eIF-3 is the physiologically significant form. Moreover, further analysis on $\mathrm{CsCl}$ gradients shows most $[58,59]$ or all [57] of the initiator tRNA in cellular ' $40 \mathrm{~S}$ ' ribosomal particles to be in species that contain about $700000 \mathrm{Da}$ of protein additional to that intrinsic to the subunits themselves, an amount consistent with the presence of eIF-3 [60]. In vitro, eIF-3 can bind to $40 \mathrm{~S}$ ribosomal subunits independently of eIF-2 or ternary complexes, and it alters the equilibrium of re-association with $60 \mathrm{~S}$ ribosomal subunits [55]. However, a significant proportion of the free $40 \mathrm{~S}$ ribosomal subunits in cells contain only about $100000 \mathrm{Da}$ of extra protein [57-61], and, in reticulocytes at least, there are considerable amounts of eIF-3 not associated with ribosomes [62]. These observations suggest that binding of the entire eIF-3 molecule is not obligatory, and may not even be sufficient, for the existence of $40 \mathrm{~S}$ subunits in a dissociated form. Two further factors, however, have been described as having ribosome dissociation activity. One, originally isolated from wheat germ [63] and subsequently from calf liver [64] and rabbit reticulocytes [65], has been designated eIF-6. It has a molecular mass of about $25000 \mathrm{Da}$ and is thought to promote dissociation by binding to the $60 \mathrm{~S}$ ribosomal subunit. The second, known as eIF-4C (molecular mass $17500 \mathrm{Da}$ ), stimulates the labelling of $40 \mathrm{~S}$ initiation complexes formed from purified components $[52,66]$, either by stabilization [67] or by promoting dissociation of $80 \mathrm{~S}$ ribosomes into subunits [68]. Reports are contradictory as to whether this factor does $[66,68]$ or does not [54] bind to $40 \mathrm{~S}$ initiation complexes in vitro. Merrick and co-workers [54] regard this factor as being mainly involved in enhancing the $60 \mathrm{~S}$ subunit joining step.
Binding of the $43 \mathrm{~S}$ initiation complex to mRNA. This very complicated process requires at least these initiation factors, eIF-4A, eIF-4B and eIF-4F, in addition to the eIF-3 already bound to the $40 \mathrm{~S}$ ribosomal subunit (Fig. 3 ). The hydrolysis of ATP is also involved. When the binding occurs in a 'fractionated' cell-free system involving purified components the result is the formation of a complex with a sedimentation coefficient of about $48 \mathrm{~S}$, but in vivo newly initiating ribosomes normally bind to RNA molecules that are already being translated by other ribosomes. Upon analysis of the cell extract on sucrose gradients, therefore, [40 S subunit - Met-tRNA ${ }_{\mathrm{f}}$. mRNA] complexes would be expected to be found in the polysomal region of the gradients.

This step of initiation is now thought to take place in two stages: (i) association of the $43 \mathrm{~S}$ initiation complex with the $5^{\prime}$ end of the mRNA and (ii) movement of the ribosomal subunit along the mRNA until it reaches the AUG codon that constitutes the correct initiation site for translation of the message. This searching and selection mechanism was originally suggested by Kozak [69], who termed it the 'scanning model'. Both stages appear to be ATP-dependent [70].

(i) Association of the $43 \mathrm{~S}$ preinitiation complex with the $5^{\prime}$ end of mRNA. This stage involves the ATPdependent interaction of mRNA with the factors eIF-4A, eIF-4B and eIF-4F in such a way as to enable the $43 \mathrm{~S}$ complex to bind at, or very near to, the $5^{\prime}$ end (Fig. 3). eIF-4A and eIF-4B are single polypeptide chains of molecular masses around 45000 and $80000 \mathrm{Da}$ respectively $[52,53,71]$. Some confusion in the literature has arisen from the fact that partially purified preparations of eIF-3 and eIF-4B are often contaminated with one or more components of the recently discovered, complex initiation factor now known as eIF-4F [72]. This consists of at least three polypeptides, of molecular masses 
220000,46000 and $24000-26000 \mathrm{Da}$. This last subunit has binding activity towards the $5^{\prime}$ cap structure on mRNA; it was previously identified separately from the other components of eIF-4F and referred to as 'cap-binding protein I (CBP-I)', '24K-CBP' or 'eIF-4E' $[73,74]$. The $46000 \mathrm{Da}$ component of eIF-4F has been shown by peptide analysis to bear a 'strong similarity' to eIF-4A and to be recognized by a monoclonal antibody against that factor [75], but it is still not clear whether the two proteins are absolutely identical [76]. In a variety of partial reactions in vitro it seems clear that eIF-4F cannot entirely replace the need for eIF-4A, since both factors are required to act in concert to achieve maximal activity [72,77], as discussed below. The function of the 220000 Da component of eIF-4F has not been elucidated, but its integrity is clearly important for the function of the factor, as indicated by studies on the effect of poliovirus infection (see below). It is now clear that eIF-4F, as described by Grifo et al. [72] is analogous to the 'CBP-II' complex of Tahara et al. [78] and Edery et al. [75].

The precise individual roles of eIF-4A, eIF-4B and eIF-4F in mRNA binding to the $43 \mathrm{~S}$ initiation complex are not yet fully explained. The presence of all three factors is needed for optimal binding of labelled mRNA to $40 \mathrm{~S}$ subunits and for globin synthesis in cell-free systems [72]. The factors probably operate in close association with each other, since they frequently show synergistic effects when added together in partial reactions in vitro. The process of binding preinitiation complexes to mRNA and the relationships between the factors mediating it have mainly been studied at the level of such partial reactions.

The first step appears to be the binding of all these initiation factors to the $5^{\prime}$ end of mRNA. In the vast majority of cases eukaryotic mRNA bears a $5^{\prime}$ terminal cap [79], and it is specifically with this structure that the initiation factors are initially associated. It is likely that the first polypeptide to bind is the $24000 \mathrm{Da}$ component of eIF-4F, since ( $a$ ) this factor is capable of cross-linking to the cap structure in a reaction that is independent of ATP and requires neither eIF-4A nor eIF-4B $[77,80]$ and (b) neither eIF-4B [75] nor eIF-4A (whether free [71,75] or derived from eIF-4F [80]) will bind to the cap structure in the absence of the other components of eIF-4F. Indeed, a new photochemical cross-linking assay indicates no specific interaction between eIF-4A and the cap at all; it may be that data from earlier chemical cross-linking studies merely indicate close proximity rather than direct interaction between eIF-4A and cap [81].

The next step appears to be an ATP-dependent unwinding of mRNA secondary structure, which presumably generates a suitable site for the binding of the initiating ribosomal subunit. The factor eIF-4A seems to be intimately involved in this ATP-requiring process. This conclusion arises from the fact that eIF-4A can exhibit three related activities in vitro. Firstly it is able to bind ATP, as demonstrated by u.v. cross-linking studies with this ligand [76]. Secondly, the factor has ATPase activity [77]. Thirdly, in the presence of ATP, it is capable of melting mRNA structure, as demonstrated by its ability to promote structural changes in reovirus mRNAs that result in increased sensitivity to nuclease attack [80]. All these activities of eIF-4A are augmented by the presence of eIF-4B, which, however, shows none of them by itself. The most complicated aspect of this stage in the process concerns the relationship between the eIF-4A present as the free factor and the $46000 \mathrm{Da}$ component of eIF-4F. All the reactions are performed more efficiently in vitro by eIF-4F than by free eIF-4A, but in each case the two factors act synergistically when present together. By separating the component subunits of eIF-4F, Ray et al. [80] localized the mRNA unwinding activity to the $46000 \mathrm{Da}$ component, but found that significant activity was only achieved in the presence of the remainder of the complex. They suggested that the $26000 \mathrm{Da}$ component of eIF-4F, by recognizing and binding to the $5^{\prime}$ terminal cap, aligns the $46000 \mathrm{Da}$ component in such a way as to facilitate the initial, ATP-dependent melting of mRNA structure needed to allow binding of the $40 \mathrm{~S}$ ribosomal subunit. Thus eIF-4A as part of the eIF-4F complex is better able to locate the requisite site on mRNA for unwinding and is therefore much more potent than the free factor. However, the latter will function if present at high concentration, and this is probably responsible for the translation of uncapped mRNAs, such as those of polio and EMC viruses. This may explain why translation of mRNA from these viruses in cell-free systems is particularly sensitive to limitation of eIF-4A $[80,82,83]$. In HeLa cells eIF-4A is present at very high concentrations, being in 3-fold molar excess over ribosomes [84]. It seems probable that under most conditions, when capped cellular mRNAs are being translated, the function of free eIF-4A may be to promote such melting of mRNA secondary structure as is necessary to facilitate the subsequent migration of the $40 \mathrm{~S}$ subunit from the $5^{\prime}$ end of the mRNA to the initiation site. The differences between mRNA species in their requirement for eIF-4A in translation assays $[82,83,85,86]$ may reflect differences in the nature or extent of secondary structure in their $5^{\prime}$ untranslated regions.

(ii) Movement of the initiation complex along the mRNA and selection of the correct AUG start site. The roles, if any, of initiaton factors in this process are still unknown, and most attention has been given to that of mRNA structure or nucleotide sequence in guiding the initiating $40 \mathrm{~S}$ ribosomal subunit to the correct start site $[10,87]$. Kozak originally proposed that $40 \mathrm{~S}$ subunits migrate along the mRNA from the $5^{\prime}$ end and stop at the first AUG codon they reach, whereupon the initiation codon interacts with the anti-codon on the Met-tRNA bound to the $40 \mathrm{~S}$ subunit [69]. There are few exceptions, however, where initiation begins at a second or subsequent AUG. This led Kozak to evaluate the role of contiguous nucleotide sequences in determining the effectiveness of AUG codons as initiation sites. As a result of these studies she has proposed $\mathrm{CC}_{\mathrm{G}}^{\mathrm{A}} \mathrm{CCAUGG}$ as a consensus sequence for strong initiation sites [88-90], with the nucleotides at the -3 and +4 positions relative to the AUG codon being particularly crucial. The 'optimal context' for an initiation codon is the presence of a purine at each of these positions, with $A$ preferred at -3 and $G$ at +4 . When additional AUG triplets are inserted upstream from the normal site in a cloned preproinsulin gene [91], such triplets are able to intercept ribosomes and promote premature initiation, thereby preventing the ribosomes from reaching the usual site for initiation of proinsulin synthesis; the ability of AUG codons to intercept ribosomes shows the same dependency 

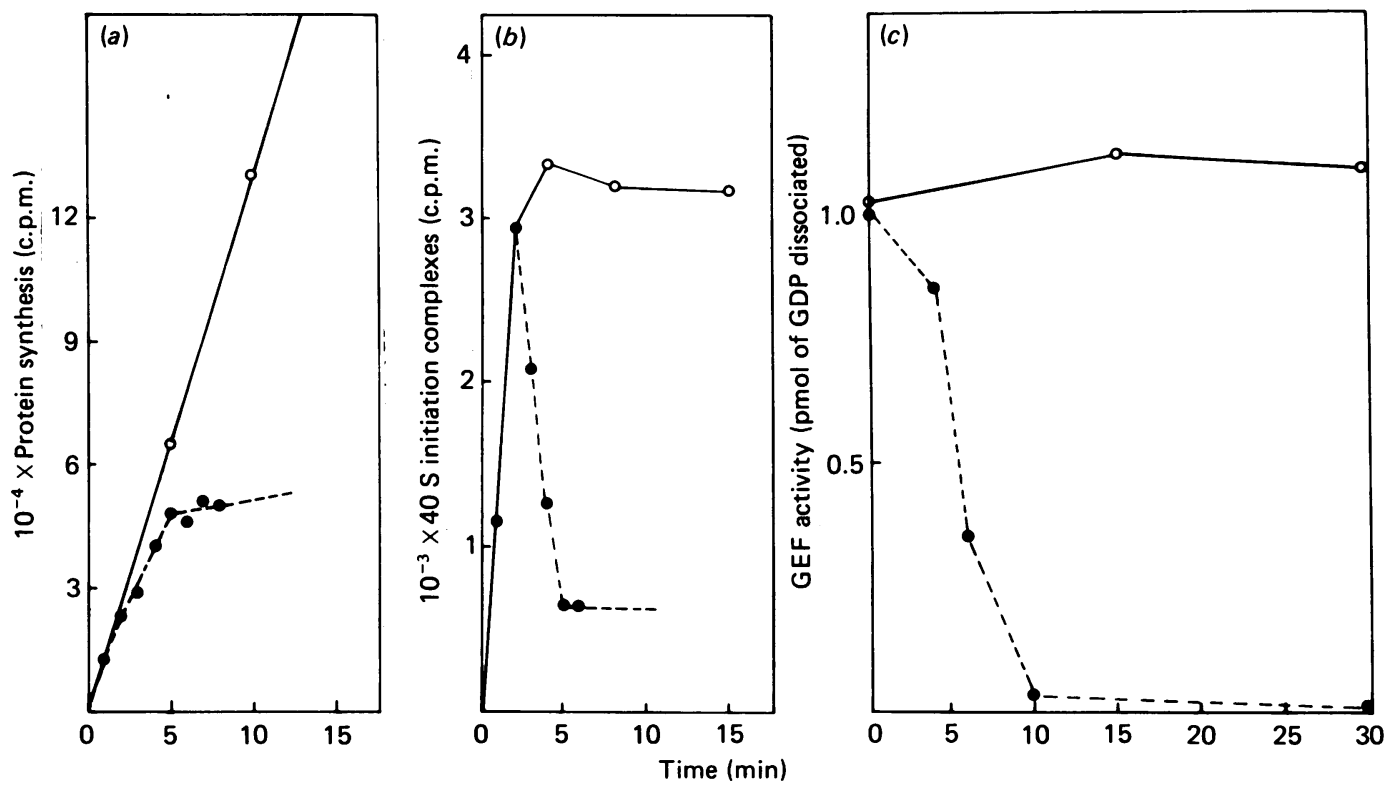

Fig. 4. Effect of haem deprivation of the reticulocyte lysate on: (a) incorporation of $\left[{ }^{35}\right.$ S]methionine into protein, (b) labelling of $43 \mathrm{~S}$ initiation complexes with $\left[{ }^{35}\right.$ S]methionine (as Met-tRNA $A_{f}$ and (c) GEF activity, measured as the dissociation of [ $\left.{ }^{3} \mathrm{H}\right] \mathrm{GDP}$ from exogenous [eIF-2· $\left.\left[{ }^{3} \mathrm{H}\right] \mathrm{GDP}\right]$ added $2 \mathrm{~min}$ before sampling

Data for panels $(a)$ and $(b)$ are from Legon et al. [94] and for panel (c) from Matts \& London [106]. - , lysate incubated in the presence of haem;----, lysate incubated in the absence of haem.

on the surrounding sequences as found for natural initiation sites. In addition, the prematurely initiated ribosomes can, if a termination codon intervenes, terminate translation and then travel on down the mRNA and re-initiate at the usual proinsulin start site. This type of mechanism could account for the translation of certain viral messages, which had hitherto constituted a problem for the scanning hypothesis because they were known to initiate translation at 'weak' sites downstream from sites with much better sequence context [91].

Pelletier \& Sonenberg [92] have looked at the role of secondary structure of mRNA in the initiation of translation. They found that insertion mutagenesis designed to produce hairpin loops in the $5^{\prime}$ untranslated region decreases the translational efficiency. This suggests that differences between mRNA species in the extent of secondary structure in this region may affect their relative abilities to be recruited for translation. These workers have now found that insertion of extra secondary structure may inhibit translation by different mechanisms, depending on the position of the insertion [81]. An insertion very close to the $5^{\prime}$ terminal cap appears to interfere with the interaction of eIF-4B with the cap structure, whereas one further from the $5^{\prime}$ end has no effect on this interaction and presumably affects the subsequent migration of the $40 \mathrm{~S}$ subunit to the initiation site.

Addition of the $60 \mathrm{~S}$ subunit. This step requires another initiation factor, eIF-5, and involves the release of eIF-2 and eIF-3 from the $40 \mathrm{~S}$ subunit [52-54,93]. The release of these factors requires the hydrolysis of the GTP molecule originally bound as part of the ternary complex; release cannot occur if a nonhydrolysable analogue is bound instead. The GTP- and eIF-5-catalysed release can occur in vitro in the absence of $60 \mathrm{~S}$ ribosomal subunits, suggesting that in vivo it precedes subunit joining [22,93]. As mentioned earlier, it is likely that eIF-2 is released as a binary complex with the GDP produced by hydrolysis.

Regulation of initiation of protein synthesis in mammalian cells

Formation of $43 \mathrm{~S}$ preinitiation complexes. The most widely used system for the study of translational control has been the rabbit reticulocyte lysate, which retains much of the protein-synthetic activity of the parent cells. Protein synthesis in the lysate is almost completely dependent on the presence of haemin, reflecting the need for continuous haem synthesis in the intact cells. Whilst the physiological significance is related to the fact that more than $90 \%$ of the protein synthesized is globin, haem actually regulates the translation of all types of protein being made in this system. In the absence of haem, protein synthesis proceeds normally for about 5-10 min, then the rate falls abruptly to about $10 \%$ of the control rate (Fig. 4, panel $a$ ). This very clear-cut response has been studied in great detail over the last 20 years as a model system of translational control.

The 'shut-off' of protein synthesis in haem-deprived lysates is associated with a number of events.

(i) Disaggregation of polysomes and accumulation of $80 \mathrm{~S}$ monomeric ribosomes, indicating that the initiation stage is inhibited relative to elongation.

(ii) $\mathrm{A}$ fall in the concentration of $43 \mathrm{~S}$ initiation complexes detected by labelling $\left[{ }^{35} \mathrm{~S}\right]$ Met-tRNA ([94]; Fig. 4, panel $b$ ).

(iii) An increase in the extent of phosphorylation of the $\alpha(38000 \mathrm{Da})$ subunit of eIF-2 [95-98]. Only about $30-40 \%$ of the eIF-2 becomes phosphorylated in the fully inhibited state [96-98]. The phosphorylation is the result of the activation in the absence of haem of a cyclic AMP-independent kinase specific for eIF-2 $\alpha$. This kinase, 
usually termed 'HCR' (haem-controlled repressor) or 'HRI' (haem-regulated inhibitor), has been purified in several laboratories [99-102] and is very inhibitory to protein synthesis when added to active reticulocyte lysates, even in the presence of haem. The mechanism of activation of the kinase is still not fully understood [9]. Several other conditions that inhibit protein synthesis in reticulocyte lysates also do so by activating either HCR or another eIF- $2 \alpha$ kinase with a very similar mode of action $[97,103]$. The latter is a kinase activated by low concentrations of dsRNA [95,104]. This is certainly a distinct protein, but it phosphorylates eIF-2 at a site that is either identical, or very close, to the target site for HCR [105].

(iv) Lysates deprived of haem or treated with dsRNA lose the ability to displace GDP from added [eIF-2 - GDP] ([106]; Fig. 4, panel c). This measures the guaninenucleotide-exchange reaction that is necessary for the recycling of eIF-2 between successive rounds of initiation. The rate of protein synthesis can be restored by addition of catalytic amounts of exogenous purified GEF to the inhibited lysate $[25,34,106]$. Moreover, phosphorylation of purified [eIF-2 GDP] binary complexes with HCR blocks the ability of GEF to stimulate either the displacement of the GDP or the formation of ternary complexes with Met-tRNA and GTP [23-26,31,32,107-109]. Obviously something is wrong with the ability of $\alpha$-phosphorylated eIF-2 to interact productively with the exchange factor, GEF. However, the exact nature of this lesion is still far from clear.

The simplest possible mechanism would be if eIF-2 were, when phosphorylated, to lose its ability to interact with GEF at all. However, two key observations are inconsistent with such a mechanism. Firstly, eIF-2 only becomes phosphorylated to a limited extent $[96,98]$. This leads one to ask why protein synthesis cannot be maintained, at least to a moderate extent, by the substantial proportion of eIF-2 that remains unphosphorylated. Secondly, far from being unable to interact with GEF, phosphorylated eIF-2 seems to show a greater tendency to form a 'heavy' complex with the exchange factor, detectable on sucrose or glycerol density gradients, provided that GDP is present in the assay mixture $[24,26,30,32]$. The mechanism proposed to explain these observations is one in which phosphorylated eIF-2 forms an excessively stable complex with GEF, effectively sequestering the GEF so that it is unavailable for the recycling of the remaining unphosphorylated eIF-2 in the lysate [24-26,29,31,106]. This theory depends on there being in the lysate a considerable excess of eIF-2 relative to GEF such that phosphorylation of a relatively small proportion of the eIF-2 is sufficient to 'mop up' virtually all the exchange factor. This is widely believed to be the case, but the quantification is at present extremely shaky, since no reliable method yet exists for direct determination of the molar concentration of GEF in cells and extracts.

A point which has tended to be ignored in the above studies is the subcellular localization of the components involved. Ideally, one would like to know the relative concentrations of eIF-2 and GEF in the compartment in which they interact. GEF is generally regarded as soluble rather than ribosome-bound, acting on [eIF-2-GDP] after release of the latter from the initiating ribosome at subunit joining. GEF activity is found mainly in the postribosomal supernatant of reticulocyte lysates [110] and, moreover, when purified eIF-2 binds to $40 \mathrm{~S}$ ribosomal subunits in vitro in the presence of GEF the complexes formed do not contain the GEF polypeptides $[25,26]$. One would also predict that the sequestration of GEF would result in a pile-up of [eIF-2.GDP] in the cytoplasm. However, Jagus [28] found a significant proportion of the immunologically reactive eIF-2 in the reticulocyte lysate to be associated with $40 \mathrm{~S}$ ribosomal subunits; this proportion increased in haem deprivation, a condition where Met-tRNA binding to ribosomal subunits is decreased (see Fig. 4, panel b). The accumulation of phosphorylated eIF- 2 on $40 \mathrm{~S}$ subunits has also been demonstrated in a somewhat differently manipulated reticulocyte lysate, in which eIF- $2 \alpha$ kinase was activated by dsRNA in the presence of exogenous viral mRNA [111,112].

A variation on this theme is the report by two groups that eIF-2 in reticulocyte lysates in found in association with $60 \mathrm{~S}$ ribosomal subunits $[113,114]$. In the study by Thomas et al. [113] the factor was claimed to be associated with polyribosomal $60 \mathrm{~S}$ subunits in haemsupplemented lysates, whilst in haem-deprived lysates both groups found that $\alpha$-phosphorylated factor and GDP accumulated on native $60 \mathrm{~S}$ subunits and $80 \mathrm{~S}$ monomeric ribosomes $[113,114]$. In earlier work, Thomas et al. [110] reported that over $90 \%$ of phosphorylated eIF-2 in haem-deprived lysates could be found in association with ribosomes, but this is at variance with results from my own laboratory based on assays of eIF-2 activity in postribosomal supernatants and high-salt extracts of reticulocyte ribosomes [115].

Further understanding of the cycling of initiation factors between ribosome-bound and soluble forms requires definitive evidence on their distribution between the cytoplasm and various ribosomal particles. For the eIF-2 not bound to ribosomes it is is also necessary to quantify that present as the free factor relative to that found in complexes with GEF. For the eIF-2 present in each subcellular location, we also need to know its phosphorylation status and the extent of its association

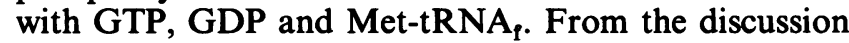
above it is obvious that the information currently available on these points is confusingly variable. The development of antibodies specific for eIF-2 $[28,84]$ and of techniques for separating the phosphorylated and unphosphorylated forms of eIF-2 by isoelectric focusing $[84,116]$ should result in the appearance of more and better data in the near future. However, another important requirement is the design of separation procedures that result in neither destabilization of physiologically relevant associations on the one hand, nor artifactual associations on the other. For example, the association of some initiation factors with ribosomal particles is very salt-sensitive. It is likely that the frequently-used practice of separating ribosomal particles in buffers whose ionic strength is substantially below that in the cell (or which is optimal for protein synthesis in the reticulocytelysate)could well result in spurious association of factors. These problems could be exacerbated by the addition of inhibitors of protein kinases and phosphatases to isolation media in experiments designed to test phosphorylation status (e.g. EDTA; R. Panniers, personal communication). Finally, the potential role of the cytoskeleton in controlling the interaction of various components of the protein synthetic machinery should not be neglected, since ribosomes, mRNA and initiation 
factors have all been found in association with this subcellular network [117-120].

The study of protein synthesis in reticulocyte lysates following gel filtration has revealed that regulation can be exerted by various compounds of low molecular mass. In particular, sugar phosphates are required to maintain a high rate of initiation in gel-filtered lysates [121-125]. These compounds act at two levels. Firstly, the oxidation of glucose 6-phosphate and related metabolites by the pentose phosphate pathway generates reducing power, which is needed to prevent the activation of the eIF- $2 \alpha$ kinase, HCR. Secondly, glucose 6-phosphate itself exerts a direct effect on the activity of eIF-2. This latter action does not involve phosphorylation of the factor, nor does it require metabolism of the glucose 6-phosphate, since 2-deoxyglucose 6-phosphate is also effective.

Role of eIF-2 phosphorylation in the regulation of protein synthesis in non-erythroid cells. Elucidation of the mechanisms controlling the rate of protein synthesis in other cells has lagged somewhat behind the studies with reticulocytes. A serious impediment to such work has been the intractability of most mammalian cell types to the preparation of cell-free protein-synthesizing systems that will sustain in vitro rates of initiation comparable with those in the parent cells. Whilst considerable improvements have been made [126,127], no mammalian cell type has yet yielded a cell-free system to rival the reticulocyte lysate. However, it is becoming clear that regulation at the level of eIF-2 function is by no means unique to the reticulocyte. Kinases and phosphatases acting on the $\alpha$-subunit of eIF- 2 have been identified in a wide variety of cells and tissues [116,128-131], though none has been characterized as extensively as HCR and the dsRNA-activated kinase from reticulocytes. GEF preparations with very similar activity and subunit structure to the reticulocyte factor have been isolated from Ehrlich ascites cells [27] and rat liver [132] and a protein fraction with GEF activity has been obtained from neuroblastoma cells [133]. However, whilst the eventual control mechanisms at the initiation level may resemble those seen in the reticulocyte, the physiological signals inducing those effects are almost certain to be different. Many conditions are now known to affect the activity and/or phosphorylation status of eIF-2,including nutrient supply, hormonal status, viral infection and heat shock.

Most work has been done with cells in culture, which can easily be subjected to rather drastic insults, such as total deprivation of one or more essential nutrients or heating to $43-45^{\circ} \mathrm{C}$, resulting in very pronounced decreases in protein synthesis. In Ehrlich ascites cells 'starved' of the essential amino acid, lysine, labelling of $43 \mathrm{~S}$ initiation complexes with $\left.{ }^{35} \mathrm{~S}\right]$ methionine is decreased both in vivo [58] and in cell-free extracts prepared from the treated cells [134]. The impaired ability of the extracts from the starved cells to form $43 \mathrm{~S}$ initiation complexes can be restored by the addition of exogenous, purified eIF-2 [134]. The use of mutants of CHO cells that are temperature-sensitive for certain aminoacyl-tRNA synthetases also suggests a connection between the activity of these enzymes and the rate of initiation. Extracts prepared from these cells after incubation at the non-permissive temperature show impaired ability to form $43 \mathrm{~S}$ initiation complexes and to catalyse displacmeent of GDP from exogenously added
[eIF-2 $\left.\left.\cdot{ }^{3} \mathrm{H}\right] \mathrm{GDP}\right][135]$. Furthermore, addition of purified [eIF-2-GEF] has a much more potent stimulatory effect on protein synthesis in extracts from cells incubated at the non-permissive temperature than in those from control cells (M. J. Clemens \& R. Panniers, personal communication).

Data on the phosphorylation status of eIF- 2 in cells in different nutritional conditions are just beginning to emerge. Duncan \& Hershey [136] examined HeLa cells which they described as 'serum depleted', but which may also have become deficient in other essential nutrients. In these depleted cells the proportion of eIF-2 in the phosphorylated form rose from a virtually undetectable level to $15-20 \%$, a change that was reversed when the cells were transferred to fresh medium. However this evident similarity to the reticulocyte system, in both the low 'control' level of eIF-2 phosphorylation and the nature and extent of the response to inhibitory conditions, does not extend to the Ehrlich ascites tumour cell. In growing Ehrlich cells the proportion of eIF-2 in the phosphorylated form is much higher (about $40 \%$ ), as originally shown by analysing partially purified eIF-2 by isoelectric focusing [116]. This has now been confirmed using rapid-sampling techniques on whole cells, with the aid of a monoclonal antibody to eIF-2 (K. Clarke \& E. C. Henshaw, unpublished work). If, as is thought, the concentration of GEF in these cells is low relative to that of eIF-2 [27], consideration of the sequestration model described in the previous section might lead one to wonder how protein synthesis ever occurs at all! Clearly there is still a great deal to learn, notably on the kinetics of interaction of eIF-2 with GEF, guanine nucleotides and $40 \mathrm{~S}$ ribosomal subunits under conditions in vivo.

Regulation of an early step in initiation also appears to be important in the response of mammalian cells to heat shock. Short periods of incubation at temperatures of $43-45^{\circ} \mathrm{C}$ have profound inhibitory effects on overall translation [137,138]. Heat-shocked Ehrlich ascites cells show decreased labelling of $43 \mathrm{~S}$ initiation complexes with [ $\left.{ }^{35} \mathrm{~S}\right] \mathrm{methionine}$ either in vivo or in cell-free extracts [137]. Duncan \& Hershey [138] demonstrated increased phosphorylation of eIF-2 after a short exposure of HeLa cells to a temperature of $45^{\circ} \mathrm{C}$, and also observed covalent modification (dephosphorylation) of one of the multiple species of eIF-4B. However, Panniers et al. [139] were unable to restore the deficit in protein synthesis by addition of eIF-2 to extracts of heat-shocked Ehrlich cells, and instead obtained the rather surprising result that rescue could be achieved by addition of the mRNA binding factor, eIF-4F, which had not previously been though to affect stages in initiation earlier than mRNA binding. This may well indicate that regulation of initiation by some conditions occurs at more than one step. Probably consistent with this is the report [140] that extracts from serum-deprived neuroblastoma cells show a defect in protein synthesis that can be reversed by the addition of exogenous eIF-4B, suggesting that serum depletion may affect later stages in initiation as well as increasing the phosphorylation of eIF-2 [136]. It is possible, however, that the eIF-4B used in the studies on neuroblastoma cell extracts [140] may have contained small amounts of eIF-4F, as is frequently found [72], and it would be of interest to determine the effect of this latter factor individually.

There is now evidence that eIF-2 activity is regulated in normal animal tissues as well as in transformed cells in 
culture. Skeletal muscle from either starved or diabetic rats shows decreased ability to form $43 \mathrm{~S}$ preinitiation complexes, either in the intact tissue [141] or in cell-free extracts [142]. The extracts from the deficient animals are also poor at forming ternary complexes and at catalysing guanine nucleotide exchange on added [eIF- $\left.2 \cdot\left[{ }^{3} \mathrm{H}\right] \mathrm{GDP}\right]$ (F. J. Kelly, I. W. Jeffrey \& V. M. Pain, unpublished work). Labelling of $43 \mathrm{~S}$ initiation complexes with $\left[{ }^{35} \mathrm{~S}\right]$ methionine is also decreased in perfused rat livers deprived of essential amino acids [143].

Viral infection, sometimes in conjunction with interferon treatment, can result in changes in eIF-2 function and/or phosphorylation. It has long been known that the concentration of an eIF-2 kinase which is activated by dsRNA in cell extracts is elevated by interferon treatment of cells [144], with the implication that the role of dsRNA in vitro mimics that of viral infection in the intact cell. Increased phosphorylation of eIF-2 has now been demonstrated in two cell types in response to viral infection together with interferon treatment $[145,146]$. Qualitatively the effects match the inhibition of protein synthesis, which also requires both infection and interferon treatment, but consideration of the respective time-courses and sizes of the effects suggests that phosphorylation of eIF-2 is not the sole mechanism modulating protein synthesis in these conditions [146]. In an earlier study [147], in which phosphorylation status was not examined, the infection of L-929 cells by vesicular stomatitis virus (VSV) was found to be associated with a fall in eIF-2 activity. Another interesting observation concerns the role of a small RNA that accumulates in the late stages of adenovirus infection. This VA I RNA appears to be important in preserving the ability of infected HeLa cells to translate not only viral RNAs but host mRNAs as well $[148,149]$. Cells infected with a mutant virus, d1331, that fails to synthesize $V A_{I}$ RNA, become defective in translation in late infection. The defect can be reproduced in cell-free systems, is associated with the accumulation of an inhibitor and cannot be reversed in vitro by the direct addition of $\mathrm{VA}_{\mathrm{I}}$ RNA [148]. Rescue can, however, be brought about by the addition of either eIF-2, or, more effectively, GEF, to the cell-free system [148], and further studies [115] confirmed that GEF activity was severely depressed in cells infected with the mutant virus. The cells also showed elevated eIF- $2 \alpha$ kinase activity, suggesting that one role of the $V_{I}$ RNA produced during infection of cells with wild-type adenovirus is to block the activation of this kinase. This has now been confirmed in another laboratory [150].

Duncan \& Hershey $[84,151]$ have used their twodimensional electrophoresis system together with immunoblotting to quantify several initiation factors in HeLa cells. There is a wide variation between the factors in their concentration, ranging from about 0.5 molecules/ribosome (eIF-4B and one of the polypeptides of eIF-3) to 3 molecules/ribosome (eIF-4A). Even the lowest of these concentrations seems surprisingly high in view of the fact that only about $5-10 \%$, at most, of cellular ribosomes are present at any one time in the form of native subunits likely to be participating in initiation [60]. It is difficult to understand the significance of the presence of such a large concentration of a factor such as eIF-2 (0.8 molecules/ribosome), for which only one molecule appears to participate in each round of initiation. The extremely high concentration of eIF-4A, even relative to the other factors, may reflect the simultaneous involvement of more than one molecule of the factor in unwinding the $5^{\prime}$ end of each molecule of mRNA. Duncan \& Hershey [151] also examined the effect of nutrient deprivation on the concentrations of some of the initiation factors in HeLa cells. As might be expected, the concentrations gradually fell as the cells became depleted, roughly in parallel with a fall in the ribosome concentration. The effect, however, was certainly not large enough to account for the pronounced inhibition of initiation of protein synthesis that occurred under these conditions. None of the factors appeared to have a spectacularly rapid turnover rate, and it seems unlikely that changes in the cellular concentrations of initiation factors would play a major role in the acute regulation of protein synthesis in response to such conditions as heat shock or amino acid starvation.

Regulations at the level of mRNA binding to $43 \mathrm{~S}$ initiation complexes. The best-studied example of control at this level is the effect of poliovirus infection, which virtually eliminates the synthesis of host cell proteins in vivo. Cell-free systems from the infected cells can translate polio, but not host cell, RNAs [152]. Host protein translation can be restored by the addition of a crude mixture of initiation factors (a 'salt-wash' fraction) from uninfected cells, but not by a similar preparation from polio-infected cells. Thus the latter seem to have lost an activity necessary for translation of host, but not polio, mRNA. An unusual feature of polio RNA is that it lacks a $5^{\prime}$ terminal cap structure, so an obvious potential way of favouring polio translation is to inactivate the cap recognition process. It is now known that in the salt-wash fraction from poliovirus-infected cells the ability of polypeptides corresponding to eIF-4A, eIF-4B and the 24000 Da subunit of eIF-4F to form chemical cross-links with oxidized cap structures is almost totally inhibited [153]. This binding activity [154], and the translation of host cell mRNAs in extracts from polio-infected cells $[78,155]$ are both restored by the addition of exogenous eIF-4F purified from rabbit reticulocytes. Earlier results ascribing such restorative activity to eIF-3 [156] or eIF-4B [157] probably reflect contamination of these preparations with eIF-4F. No obvious effect of infection on the intrinsic structure of eIF-4A or eIF-4B [158] or of the 24000 Da subunit of eIF-4F [154] has been found, but the overall configuration of eIF-4F appears to be altered by proteolytic degradation of its $220000 \mathrm{Da}$ subunit $[154,159,160]$. This change in configuration blocks the cap-binding activity of eIF-4F. Since the interaction of eIF-4A and eIF-4B with mRNA is dependent on the prior binding of eIF-4F, these factors are also prevented from binding when eIF-4F is inactivated by poliovirus infection. This illustrates the very strong interdependence of the activities of these factors in mRNA binding reactions. Further evidence for the causal connection between cleavage of the 220000 Da polypeptide of eIF-4F and the selective inhibition of host protein synthesis comes from studies with a constructed mutant of poliovirus in which the ability to induce both functions is lost [161].

One might have expected this mechanism to operate in cells infected by other viruses with uncapped RNAs, but this is not always the case. Whilst infection of HeLa cells with human rhinovirus 14 does induce proteolytic cleavage of the $220000 \mathrm{Da}$ unit of eIF-4F [162], infection 
with encephalomyocarditis (EMC) virus does not [163]. Inhibition of host protein synthesis by this latter virus appears to be brought about by a number of different mechanisms, depending on the type of cell infected, but in no case by a mechanism similar to that resulting from polio infection [164]. It also appears that cleavage of the large subunit of eIF-4F has been excluded as a mechanism operating in infection with mengovirus, reovirus and vaccinia [163].

\section{Future studies}

I will conclude this brief review by summarizing some of the areas in which the most rapid advances can now be expected. It is likely that our knowledge of the structure, function and turnover of the individual initiation factors will improve with the further development of antibodies to these proteins and with the cloning and sequencing of the genes that code for the factors. In particular it will be instructive to discover the relative amounts of the different factors which interact with each other, and whether these can change in response to physiological signals. Sequencing studies will also be helpful in identifying the precise sites on initiation factors to which ligands bind or which become covalently modified. Use of genetic engineering techniques to modify the primary and secondary structures of specific mRNAs will yield further information on the sequences that determine initiation efficiency and other properties. At the level of translational control through covalent modification of factors, much remains to be discovered about the phosphorylation of eIF-2. To what extent does this regulate eIF-2 function in systems other than reticulocytes? Can GEF and/or eIF-2 activity be altered by other mechanisms? What is the ratio of GEF to eIF-2 in different cell types, and what is the precise nature of the interaction between these two proteins? More information is likely to be forthcoming about naturally occurring molecules like the adenovirus VA $\mathrm{V}_{\mathrm{I}} \mathrm{RNA}$, which may regulate eIF-2 kinases, not only in virus-infected or transformed cells but also in normal cells and tissues. Finally, we may expect to see more examples of translational regulation at the step of mRNA binding to $43 \mathrm{~S}$ initiation complexes. The field of polypeptide chain initiation in eukaryotic cells undoubtedly has many more suprises to reveal.

I am very grateful to Bill Merrick for letting me use one of his slides as the basis for Figs. 1 and 3 and for guiding me through the maze of mRNA binding factors. Writing this review has been helped by discussions with a number of people, and I am grateful to Richard Panniers, Kathy Clarke and Bill Merrick for allowing me to quote their work prior to publication. I would like to thank Mike Clemens for his help and useful suggestions during the preparation of the manuscript, and both him and Ed Henshaw for continually sharing their ideas and enthusiasm. The work in my laboratory is supported by the Medical Research Council.

\section{References}

1. Metzler, D. E. (1977) Biochemistry: The Chemical Reactions of the Living Cell, Academic Press, New York

2. Stryer, L. (1981) Biochemistry, 2nd edn., W. H. Freeman \& Co., San Francisco

3. Adams, R. L. P., Burdon, R. H., Campbell, A. P., Leader, D. P. \& Smelli, R. M. S. (1981) The Biochemistry of the Nucleic Acids, 9th edn., Chapman \& Hall, London
4. Lewin, B. (1983) Genes, John Wiley \& Sons, New York

5. Mainwaring, W. I. P., Parish, J. H., Pickering, J. D. \& Mann, N. H. (1982) Nucleic Acid Biochemistry and Molecular Biology, Blackwell Scientific, Oxford

6. Bodley, J. W. (1983) in Biochemistry (Zubay, G., ed.), Addison-Wesley, Reading, MA

7. Austin, S. A. \& Kay, J. E. (1982) Essays Biochem. 18, 79-120

8. Maitra, U., Stringer, E. A. \& Chaudhuri, A. (1982) Annu. Rev. Biochem. 51, 869-900

9. Ochoa, S. (1983) Arch. Biochem. Biophys. 223, 325-349

10. Kozak, M. (1983) Microbiol. Rev. 47, 1-45

11. Kaempfer, R. (1984) Compr. Virol. 19, 99-175

12. Moldave, K. (1985) Annu. Rev. Biochem. 54, 1109-1149

13. Lloyd, M. A., Osborne, J. R., Safer, B., Powell, G. M. \& Merrick, W. C. (1980) J. Biol. Chem. 255, 1189-1193

14. Stringer, E. A., Chaudhuri, A. \& Maitra, U. (1979) J. Biol. Chem. 254, 6845-6848

15. Stringer, E. A., Chaudhuri, A., Valenzuela, D. \& Maitra, U. (1980) Proc. Natl. Acad. Sci. U.S.A. 77, 3356-3359

16. Mitsui, K.-I., Datta, A. \& Ochoa, S. (1981) Proc. Natl. Acad. Sci. U.S.A. 78, 4128-4132

17. Das, A., Bagchi, M. K., Ghosh-Dastidar, P. \& Gupta, N. K. (1982) J. Biol. Chem. 257, 1282-1288

18. Zardeneta, G., Kramer, G. \& Hardesty, B. (1982) Proc. Natl. Acad. Sci. U.S.A. 79, 3148-3161

19. Barrieux, A. \& Rosenfeld, M. G. (1977) J. Biol. Chem. 252, 3843-3847

20. Kurzchalia, T. V., Bommer, U.-A., Babkina, G. T. \& Karpova, G. G. (1984) FEBS Lett. 175, 313-316

21. Walton, G. M. \& Gill, G. N. (1975) Biochim. Biophys. Acta 390, 231-245

22. Raychaudhuri, P., Chaudhuri, A. \& Maitra, U. (1985) J. Biol. Chem. 260, 2140-2145

23. Siekierka, J., Mauser, L. \& Ochoa, S. (1982) Proc. Natl. Acad. Sci. U.S.A. 79, 2537-2540

24. Matts, R. L., Levin, D. H. \& London, I. M. (1983) Proc. Natl. Acad. Sci. U.S.A. 80, 2559-2563

25. Konieczny, A. \& Safer, B. (1983) J. Biol. Chem. 258, 3402-3408

26. Salimans, M., Goumans, H., Amesz, H., Benne, R. \& Voorma, H. O. (1984) Eur. J. Biochem. 145, 91-98

27. Panniers, R. \& Henshaw, E. C. (1983) J. Biol. Chem. 258, 7928-7934

28. Jagus, R. (1983) in Posttranslational Covalent Modifications of Proteins (Johnson, B. C., ed.), pp 159-179, Academic Press, New York

29. Safer, B. (1983) Cell 33, 7-8

30. Safer, B. (1984) in Gene Expression, Alfred Benzon Symp. 19 (Clark, B. F. C. \& Petersen, H. U., eds.), pp. 77-98, Munskgaard, Copenhagen

31. Siekierka, J., Manne, V., Mauser, L. \& Ochoa, S. (1983) Proc. Natl. Acad. Sci. U.S.A. 80, 1232-1235

32. Siekierka, J., Manne, V. \& Ochoa, S. (1984) Proc. Natl. Acad. Sci. U.S.A. 81, 352-356

33. Goss, D. J., Parkhurst, L. J., Mehta, H. B., Woodley, C. L. \& Wahba, A. J. (1984) J. Biol. Chem. 259, 7374-7377

34. Amesz, H., Goumans, H., Haubrich-Morree, T., Voorma H. A. \& Benne, R. (1979) Eur. J. Biochem. 98, 513-520

35. de Haro, C. \& Ochoa, S. (1979) Proc. Natl. Acad. Sci. U.S.A. 76, 2163-2164

36. Siekierka, J., Mitsui, K. \& Ochoa, S. (1981) Proc. Natl. Acad. Sci. U.S.A. 78, 220-223

37. Ralston, R. O., Das, A., Dasgupta, A., Roy, R., Palmeiri, S. \& Gupta, N. K. (1978) Proc. Natl. Acad. Sci. U.S.A. 75, 4858-4862

38. Das, A., Ralston, R. O., Grace, M., Roy, R., GhoshDastidar, P., Das, H. K., Yaghmai, B., Palmeiri, S. \& Gupta, N. K. (1979) Proc. Natl. Acad. Sci. U.S.A. 76, 5076-5079

39. Das, A., Bagchi, M., Roy, R., Ghosh-Dastidar, P. \& Gupta, N. K. (1982) Biochem. Biophys. Res. Commun. 104, 89-98 
40. Manchester, K. L. (1985) FEBS Lett. 182, 15-19

41. Voorma, H. O., Goumans, H., Amesz, H. \& Benne, R. (1983) Curr. Top. Cell. Regul. 22, 51-70

42. Safer, B. \& Jagus, R. (1979) Proc. Natl. Acad. Sci. U.S.A. 76, 1094-1098

43. Crouch, D. \& Safer, B. (1980) J. Biol. Chem. 255, 7918-7924

44. Granowski, N., Lehmusvitta, D., Kramer, G. \& Hardesty, B. (1980) J. Biol. Chem. 255, 310-317

45. Crouch, D. \& Safer, B. (1984) J. Biol. Chem. 259, 10363-10368

46. Stewart, A. A., Crouch, D., Cohen, P. \& Safer, B. (1980) FEBS Lett. 119, 116-119

47. Pato, M. D., Adelstein, R. S., Crouch, D., Safer, B., Ingebritsen, T. S. \& Cohen, P. (1983) Eur. J. Biochem. 132, 283-287

48. Tuazon, P. T., Merrick, W. C. \& Traugh, J. A. (1980) J. Biol. Chem. 255, 10954-10958

49. De Paoli-Roach, A. A., Roach, P. J., Pham, K., Kramer, G. \& Hardesty, B. (1981) J. Biol. Chem. 256, 88718874

50. Tahara, S. M. \& Traugh, J. A. (1982) Eur. J. Biochem. 126, 395-399

51. Schatzmann, R. C., Grifo, J. A., Merrick, W. C. \& Kuo, J. F. (1983) FEBS Lett. 159, 167-170

52. Trachsel, H., Erni, B. \& Staehelin, T. (1977) J. Mol. Biol. 116, 755-767

53. Benne, R. \& Hershey, J. W. B. (1978) J. Biol. Chem. 253, 3078-3087

54. Peterson, D. T., Merrick, W. C. \& Safer, B. (1979) J. Biol. Chem. 254, 2509-2516

55. Trachsel, H. \& Staehelin, T. (1979) Biochim. Biophys. Acta 565, 305-314

56. Benne, R. \& Hershey, J. W. B. (1976) Proc. Natl. Acad. Sci. U.S.A. 73, 3005-3009

57. Smith, K. E. \& Henshaw, E. C. (1975) J. Biol. Chem. 250, 6880-6884

58. Pain, V. M. \& Henshaw, E. C. (1975) Eur. J. Biochem. 57, 335-342

59. van Venrooij, W. J., Janssen, A. P. M., Hoeymakers, J. H. \& de Man, B. M. (1976) Eur. J. Biochem. 64, 429-435

60. Hirsch, C. A., Cox, M., van Venrooij, W. J. \& Henshaw, E. C. (1973) J. Biol. Chem. 248, 4377-4385

61. Sameshima, M. \& Izawa, M. (1975) Biochim. Biophys. Acta 378, 405-414

62. Mengod, G. \& Trachsel, H. (1985) Biochim. Biophys. Acta 825, 169-174

63. Russell, D. W. \& Spremulli, L. L. (1979) J. Biol. Chem. 254, 8796-8800

64. Valenzuela, D. M., Chaudhuri, A. \& Maitra, U. (1982) J. Biol. Chem. 257, 7712-7719

65. Raychaudhuri, P., Stringer, E. A., Valenzuela, D. M. \& Maitra, U. (1982) J. Biol. Chem. 259, 11930-11935

66. Goumans, H., Thomas, A., Verhoeven, X., Voorma, H. O. \& Benne, R. (1980) Biochim. Biophys. Acta 608, 39-46

67. Erni, B. \& Staehelin, T. (1983) Biochim. Biophys. Acta 740, 373-378

68. Thomas, A., Goumans, H., Voorma, H. O. \& Benne, R. (1980) Eur. J. Biochem. 107, 39-45

69. Kozak, M. (1978) Cell 15, 1109-1123

70. Kozak, M. (1980) Cell 22, 459-467

71. Grifo, J. A., Tahara, S. M., Leis, J. P., Morgan, M. A., Shatkin, A. J. \& Merrick, W. C. (1982) J. Biol. Chem. 257, 5246-5252

72. Grifo, J. A., Tahara, S. M., Morgan, M. A., Shatkin, A. J. \& Merrick, W. C. (1983) J. Biol. Chem. 258, 5804 5810

73. Sonenberg, N., Morgan, M. A., Merrick, W. C. \& Shatkin, A. J. (1978) Proc. Natl. Acad. Sci. U.S.A. 75, 4843-4847

74. Sonenberg, N., Rupprecht, K. M., Hecht, S. M. \& Shatkin, A. J. (1979) Proc. Natl. Acad. Sci. U.S.A. 76, 4345-4349
75. Edery, I., Humbelin, M., Darveau, A., Lee, K. A. W., Milburn, S., Hershey, J. W. B., Trachsel, H. \& Sonenberg, N. (1983) J. Biol. Chem. 258, 11398-11403

76. Sarkar, G., Edery, I. \& Sonenberg, N. (1985) J. Biol. Chem. 260, 13831-13837

77. Grifo, J. A., Abramson, R. D., Satler, C. A. \& Merrick, W. C. (1984) J. Biol. Chem. 259, 8648-8654

78. Tahara, S. M., Morgan, M. A. \& Shatkin, A. J. (1981) J. Biol. Chem. 256, 7691-7694

79. Shatkin, A. J. (1976) Cell 9, 645-653

80. Ray, B. K., Lawson, T. G., Kramer, J. C., Cladaras, M. H., Grifo, J. A., Abramson, R. D., Merrick, W. C. \& Thach, R. E. (1985) J. Biol. Chem. 260, 7651-7658

81. Pelletier, J. \& Sonenberg, N. (1985) Mol. Cell. Biol. 5, 3222-3230

82. Daniels-McQueen, S., Detjen, B. M., Grifo, J. A., Merrick, W. C. \& Thach, R. E. (1983) J. Biol. Chem. 256, 7195-7199

83. Staehelin, T., Trachsel, H., Erni, B., Boschetti, A., \& Schreier, M. H. (1975) FEBS Symp. 10, 309-323

84. Duncan, R. \& Hershey, J. W. B. (1983) J. Biol. Chem. 258, 7228-7235

85. Kabat, D. \& Chappell, M. R. (1977) J. Biol. Chem. 252, 2684-2690

86. Ray, B. K., Brendler, T. G., Adya, S., Daniels-McQueen, S., Miller, J. K., Hershey, J. W. B., Grifo, J. A., Merrick, W. C. \& Thach, R. E. (1982) Proc. Natl. Acad. Sci. U.S.A. 80, 663-667

87. Hunt, T. (1985) Nature (London) 316, 580-581

88. Kozak, M. (1981) Nucleic Acids Res. 9, 5233-5252

89. Kozak, M. (1984) Nucleic Acids Res. 12, 857-872

90. Kozak, M. (1984) Nature (London) 308, 241-246

91. Kozak, M. (1984) Nucleic Acids Res. 12, 3873-3893

92. Pelletier, J. \& Sonenberg, N. (1985) Cell 40, 515-526

93. Peterson, D. T., Safer, B. \& Merrick, W. C. (1979) J. Biol. Chem. 254, 7730-7735

94. Legon, S., Jackson, R. J. \& Hunt, T. (1973) Nature (London) New Biol. 241, 150-152

95. Farrell, P., Balkow, K., Hunt, T., Jackson, R. J. \& Trachsel, H. (1977) Cell 11, 187-200

96. Farrell, P., Hunt, T. \& Jackson, R. J. (1978) Eur. J. Biochem. 89, 517-521

97. Ernst, V., Levin, D. H. \& London, I. M. (1979) Proc. Natl. Acad. Sci. U.S.A. 76, 2118-2122

98. Leroux, A. \& London, I. M. (1982) Proc. Natl. Acad. Sci. U.S.A. 79, 2147-2151

99. Gross, M. \& Rabinovitz, M. (1973) Biochem. Biophys. Res. Commun. 50, 832-838

100. Ranu, R. S. \& London, I. M. (1979) Methods Enzymol. 60, 459-484

101. Trachsel, H., Ranu, R. S. \& London, I. M. (1979) Methods Enzymol. 60, 485-495

102. Jackson, R. J. \& Hunt, T. (1985) Biochim. Biophys. Acta, in the press

103. Jackson, R. J. (1982) in Protein Synthesis in Eukaryotes, NATO Study Institute, Series A, Life Sciences, vol. 41 (Perez-Bercoff, E., ed.), pp. 363-418, Plenum Press, New York

104. Levin, D. H., Petryshyn, R. \& London, I. M. (1980) Proc. Natl. Acad. Sci. U.S.A. 77, 832-836

105. Ernst, V., Levin, D. H., Leroux, A. \& London, I. M. (1980) Proc. Natl. Acad. Sci. U.S.A. 77, 1286-1291

106. Matts, R. L. \& London, I. M. (1984) J. Biol. Chem. 259, 6708-6711

107. Benne, R., Salimans, M., Goumans, H., Amesz, H., \& Voorma, H. O. (1980) Eur. J. Biochem. 104, 501-509

108. Clemens, M. J., Pain, V. M., Wong, S.-T. \& Henshaw, E. C. (1982) Nature (London) 296, 93-95

109. Pain, V. M. \& Clemens, M. J. (1983) Biochemistry 22, 726-733

110. Thomas, N. S. B., Matts, R. L., Petryshyn, R. \& London, I. M. (1984) Proc. Natl. Acad. Sci. U.S.A. 81, 69987002 
111. de Benedetti, A. \& Baglioni, C. (1983) J. Biol. Chem. 258, 14556-14562

112. de Benedetti, A. \& Baglioni, C. (1985) J. Biol. Chem. 260, 3135-3139

113. Thomas, N. S. B., Matts, R. L., Levin, D. H. \& London, I. M.(1985) J. Biol. Chem. 260, 9860-9866

114. Gross, M., Redman, R. \& Kaplansky, D. (1985) J. Biol. Chem. 260, 9491-9500

115. Proud, C. G., Clemens, M. J. \& Pain, V. M. (1982) FEBS Lett. 148, 214-220

116. Wong, S.-T., Mastropaolo, W. \& Henshaw, E. C. (1982) J. Biol. Chem. 257, 5231-5238

117. Lenk, R., Ransom, L., Kaufman, Y. \& Penman, S. (1977) Cell 10, 67-78

118. van Venrooij, W. J., Sillekens, P. T. G., van Eekelen, C. A. G. \& Reinders, R. J. (1981) Exp. Cell Res. 135, 79-91

119. Cervera, M., Dreyfuss, G. \& Penman, S. (1981) Cell 23, $113-120$

120. Howe, J. \& Hershey. J. W. B. (1983) Cell 37, 85-93

121. Ernst, V., Levin, D. H. \& London, I. M. (1978) J. Biol. Chem. 253, 7163-7172

122. Jackson, R. J., Campbell, E. A., Herbert, P. \& Hunt, T. (1983) Eur. J. Biochem. 131, 289-301

123. Hunt, T., Herbert, P., Campbell, E. A., Delidakis, C. \& Jackson, R. J. (1983) Eur. J. Biochem. 131, 303-311

124. Jackson, R. J., Herbert, P., Campbell, E. A. \& Hunt, T. (1983) Eur. J. Biochem. 131, 313-324

125. Michelson, A. M., Ernst, V., Levin, D. H. \& London, I. M. (1984) J. Biol. Chem. 259, 8529-8533

126. Henshaw, E. C. \& Panniers, R. (1983) Methods Enzymol. 101, 616-629

127. Morley, S. J. \& Jackson, R. J. (1985) Biochim. Biophys. Acta 825, 45-56

128. Proud, C. G. \& Pain, V. M. (1982) FEBS Lett. 143, 55-59

129. Delaunay, J., Ranu, R. S., Levin, D. H., Ernst, V. \& London, I. M. (1977) Proc. Natl. Acad. Sci. U.S.A. 74, 2264-2268

130. Siekierka, J., Mariano, T. M., Reichel, P. A. \& Mathews, M. B. (1985) Proc. Natl. Acad. Sci. U.S.A. 82, 19591963

131. Lengyel, P. (1982) Annu. Rev. Biochem. 51, 251-282

132. Colthurst, D. R. \& Proud, C. G. (1985) Biochem. Soc. Trans. 13, 756-757

133. Salimans, M., Posno, M., Benne, R. \& Voorma, H. O. (1985) Biochim. Biophys. Acta 825, 384-392

134. Pain, V. M., Lewis, J. A., Huvos, P., Henshaw, E. C. \& Clemens, M. J. (1980) J. Biol. Chem. 255, 1486-1491

135. Austin, S. A., Pollard, J. W., Jagus, R. \& Clemens, M. J. (1986) Eur. J. Biochem., in the press

136. Duncan, R. \& Hershey, J. W. B. (1985) J. Biol. Chem. 260, 5493-5497

137. Panniers, R. \& Henshaw, E. C. (1984) Eur. J. Biochem. 140, 209-214
138. Duncan, R. \& Hershey, J. W. B. (1984) J. Biol. Chem. 259, 11882-11889

139. Panniers, R., Stewart, E. B., Merrick, W. C. \& Henshaw, E. C. (1985) J. Biol. Chem. 260, 9648-9653

140. Salimans, M. M., Van Heugten, H. A. A., van Steeg, H. \& Voorma, H. O. (1985) Biochim. Biophys. Acta 824, 16-26

141. Kelly, F. J. \& Jefferson, L. S. (1985) J. Biol. Chem. 260, $6677-6683$

142. Harmon, C. S., Proud, C. G. \& Pain, V. M. (1984) Biochem. J. 223, 687-696

143. Flaim, K. E., Liao, W. S. L., Peavy, D. E., Taylor, J. M. \& Jefferson, L. S. (1982) J. Biol. Chem. 257, 2939-2946

144. Kimchi, A., Zilberstein, A., Schmidt, A., Shulman, L. \& Revel, M. (1979) J. Biol. Chem. 254, 9846-9853

145. Samuel, C. E., Duncan, R., Knutson, G. S. \& Hershey, J. W. B. (1984) J. Biol. Chem. 259, 13451-13457

146. Rice, A. P., Duncan, R., Hershey, J. W. B. \& Kerr, I. M. (1985) J. Virol. 54, 894-898

147. Centrella, M. \& Lucas-Lenard, J. (1982) J. Virol. 41, 781-791

148. Reichel, P., Merrick, W. C., Siekierka, J. \& Mathews, M. B. (1985) Nature (London) 313, 196-200

149. Svensson, C. \& Akusjarvi, G. (1985) EMBO J. 4, 957-964

150. Schneider, R. J., Safer, B., Munemitsu, S. M., Samuel, C. E. \& Schenk, T. (1985) Proc. Natl. Acad. Sci. U.S.A. 82, 4321-5325

151. Duncan, R. \& Hershey, J. W. B. (1985) J. Biol. Chem. 260, 5486-5492

152. Ehrenfeld, E. (1983) Cell 28, 435-436

153. Lee, K. A. W. \& Sonenberg, N. (1982) Proc. Natl. Acad. Sci. U.S.A. 79, 3447-3451

154. Lee, K. A. W., Edery, I. \& Sonenberg, N. (1985) J. Virol. 54, 515-524

155. Edery, I., Lee, K. A. W. \& Sonenberg, N. (1984) Biochemistry 23, 2456-2462

156. Helentjaris, T., Ehrenfeld, E., Brown-Luedi, M. L. \& Hershey, J. W. B. (1979) J. Biol. Chem. 254, 10973-10978

157. Rose, J. K., Trachsel, H., Leong, K. \& Baltimore, D. (1978) Proc. Natl. Acad. Sci. U.S.A. 75, 2732-2736

158. Duncan, R., Etchison, D. \& Hershey, J. W. B. (1983) J. Biol. Chem. 258, 7236-7239

159. Etchison, D., Milburn, S. C., Edery, I., Sonenberg, N., \& Hershey, J. W. B. (1982) J. Biol. Chem. 257, 14806-14810

160. Etchison, D., Hansen, J., Ehrenfeld, E., Edery, I., Sonenberg, N., Milburn, S. \& Hershey, J. W. B. (1984) J. Virol. 51, 832-837

161. Bernstein, H. D., Sonenberg, N. \& Baltimore, D. (1985) Mol. Cell. Biol. 5, 2913-2923

162. Etchison, D. \& Fout, S. (1985) J. Virol. 54, 634-638

163. Mosenkis, J., Daniels-McQueen, S., Janovec, S., Duncan, R., Hershey, J. W. B., Grifo, J. A., Merrick, W. C. \& Thach, R. E. (1985) J. Virol. 54, 643-645

164. Jen, G. \& Thach, R. E. (1982) J. Virol. 43, 250-261 